Original Research Paper

\title{
Integration of Anti-Corruption Education in School's Activities
}

\author{
Kokom Komalasari and Didin Saripudin \\ Faculty of Social Sciences Education, Indonesia University of Education, Bandung, Indonesia
}

Article history

Received: 14-04-2015

Revised: 21-05-2015

Accepted: 03-07-2015

Corresponding Author: Kokom Komalasari Faculty of Social Sciences

Education, Indonesia

University of Education,

Bandung, Indonesia

Email: komalasari110@yahoo.com

\begin{abstract}
The eradication of corruption is a long process, not only through law mechanism but also establishing new philosophy in form of seeding the logical reasoning and new values of free-corruption through formal education. By education, the character of anti-corruption will be created such as cultivating honesty, hard working, bravery, responsibility, independence, simplicity, justice and tolerance values. The article will describe how the anti-corruption education is integrated in school activities in Indonesia, namely in civic education and the habituation program at school. Articles based on the results of a naturalistic inquiry in middle and high school implementing anti-corruption education in Bandung, West Java, Indonesia. Therefore, the content of anti-corruption education material is included in civic education subject curriculum. Anti-corruption learning in civic education subject is done through contextual teaching and learning and value learning approaches. Besides that, module of anticorruption education, customization of anti-corruption value through honest canteen practice and creating anti-corruption climate at schools.
\end{abstract}

Keywords: Anti-Corruption Education, School's Activities, Civic Education, Contextual Teaching and Learning

\section{Introduction}

Corruption criminal action has occurred widely and assumed to be very serious disease. Corruption does not only damage to state finance, but also becomes violation on social and economic rights, undermines democracy, damages to law regulation and deteriorate development and dims the future of nation. In such correlation, corruption does not only contain definition of power or authority violation causing financial and national asset loss, but also every policy and action can cause depression of public values.

In fact, corruption occurs in various countries in the world, so that it encourages international community to cooperate in eradicating corruption. In the case of Indonesia, a lot of experts and observers stated that compared with corruption cases in other countries, corruption phenomenon occurred in Indonesia had been chronic disease and difficult to recover (Isra, 2009).

The question is how to try to eradicate corruption in Indonesia? All state functionaries, starting from central to regional level, do not dare to corrupt the country's money. The obvious thing is that relying on Corruption Eradication Committee role is not enough because it is only able to make corruption that has been indicated into criminal case. The other way is impossible as erecting wet thread. Obviously, corruption case is not a problem related to such corruption practice. It is related to one of bad mentality of Indonesia people due to feudalism. According to Koentjaraningrat (2000), it is a mentality to break through, in which the one wants to be successful although he or she should do short cut by action violating the law norm.

When it is found the red thread that the problem of corruption is on mentality, so that it is necessity if the solving is through such bad mentality recovery. There are some efforts that can be done. First, it needs a special regulation arranging strict sanction, which is death sentence for the actor of corruption. Such effort should be supported with clear, orderly and professional operational system. It is important to make the functionaries are not brave to corrupt the country's money. Such regulation is intended to make the state functionaries are not brave to make a fool of law as they want. Second, a material of special subject teaching anticorruption education and all its bad effects for nation, people or ourselves are needed by students who still study in primary school, secondary school or university.

One of the mistakes of corruption eradication efforts was that it focused more on the effort to take action against the corruptors. There were a few attentions given to corruption preventive effort. The last, reformation era had established Corruption Eradication Commission, which was given the corrective and preventive duties of 
corruption criminal action, such as giving anti-corruption education for the community and student in school. The aim of anti-corruption education was to implant the understanding and attitude of anti-corruption.

The idea to include anti-corruption material into curriculum got the positive response from the community. The result of ICW (2008) polling of 400 respondents, $87 \%$ of them stated the needs to put anticorruption material into curriculum. The reliance of community was quite higher. Almost 200 respondents stated their reliance that anti-corruption education could be going effectively in Indonesia to control corruption attitude. The polling encompassed community's opinion about the importance of anti-corruption education. The people hoped that anti-corruption education gave knowledge about corruption and its danger, created people who had high awareness about law and broke the chain of corruption. The anti-corruption education through habituation and Citizenship Education effective to develop the student's character (Gandamana, 2014).

The important of anti-corruption education was because the problems of corruption related to mentality and values. Educational institutions were believed as the best place to disseminate and implant anti-corruption values (Keen, 2003). The students who would be nation next generation should be taught and educated early to hate and keep away from corruptive action. Moreover, they were hoped to actively fight against it by educating them in the aspects of mental, spiritual and moral because the orientation of our national education directed to make Indonesian become religious and god moral people.

This article will describe how the anti-corruption education is integrated in school activities, namely in learning and the habituation program at school in Bandung, West Java, Indonesia.

\section{Material and Methods}

The research is carried out by using the naturalistic inquiry method (Lincoln and Guba, 1985). The application of naturalistic inquiry aims to describe integration of anti-corruption education in learning and the habituation program at school. Subjects of the study were students, teachers and principals of Public and Private junior and high schools in Bandung, West Java, Indonesia. The research sample is determined through purposive sampling technique based on the best school in Anti-Corruption Education. The study sample consisted of three schools in each junior and senior high-school level (which represents public and private schools).

Data collection instruments include (1) the observation sheet of participation/observation, (2) the documentation study and (3) focus group discussions. Data analysis covers (1) reducing the data (field reports and summarizing the relevant key points); (2) categorizing and classifying data systematically; (3) displaying the data in the form of a table or image (to explain the relationship between the data); (4) conducting cross-site analysis (by comparing and analyzing the data in depth); and (5) presenting the findings (drawing general conclusions and the implications of the implementation, as well as recommendations for development) (Fraenkel and Wallen, 2008).

\section{Results}

The anti-corruption education is integrated in school activities in Junior and Senior High School in Bandung West Java Indonesia through following condition.

\section{Integration Anti-Corruption Education in Curriculum}

Curriculum 2006 states anti corruption education in competence standard and specific basic competence of Civic Education in junior and Senior High School levels. It can be seen from the Table 1 .

Based on the table, it can be analyzed that Civic Education has main portion in developing anticorruption education than other subjects. In each level, it presents the content of anti-corruption education material according to children's cognitive and moral development. In Junior High School level, the students have learnt specifically the content of anti-corruption material because it has been included in basic competence that the students should have, such as the commence to identify corruption cases and the effort to eradicate corruption in Indonesia and to describe definition of anticorruption and instruments (law and institutions) of anticorruption in Indonesia. In this level, students are introduced more about anti-corruption, identifying corruption cases, the effort of corruption eradication and the law and institutional instruments of anti-corruption.

In Senior High School level, the students have used critical thinking to analyze the effort of anti-corruption eradication in Indonesia and participative competence through participation in the effort of corruption eradication in Indonesia. Besides that, understanding, open-minded (transparent) attitude and behavior and justice in national and state life are implanted as essential values in supporting anti-corruption mentality.

\section{Contextual Learning and Value Learning}

In the context of anti-corruption education, learning can be implemented by six approaches:

- Problem-based learning is a learning approach that uses real world problem as a context for students to learn about critical thinking and problem solving skill and to acquire essential knowledge and concept from the subject. In this matter, students are involved in inquiry to solve the problems integrating skills and concepts from various subject material contents. This approach includes collecting 
information related to questions, synthesizing and presenting their discovery to others

- Project-based learning or structured-task is comprehensive teaching in which the students' learning environment (classroom) is designed in order to make students conduct inquiry toward authentic, including the deepening of subject material and doing other meaningful tasks. This approach allows the students to work independently in constructing their learning and culminating it in the real product

- Work-based learning is a teaching approach that enables the students to use work-place context to learn school-based subject material and the way such material is re-used in a workplace and various activities are integrated with subject material for the students' interest

- Service learning is the use of teaching methodology integrating societal service and school-based structure to reflect such service. Thus, it emphasizes on the correlation between service and academic learning. In other words, this approach presents a practical application of new knowledge that is needed and various skills to fulfill the needs of society through project/structured-task and other activities

- Cooperative learning is a small group approach to cooperate in maximizing the learning condition to reach the learning goals
- Value learning, such as value clarification technique (value analysis, value list, value games)

\section{Development of Anti-Corruption Education Module}

Corruption Eradication Commission develops a format of anti-corruption education intended for the students of Junior High School and Senior High School. The students learn to be honest, hard working, discipline, brave, responsible, independent, simple, just and caring. Such nine lofty values are hoped to build anti-corruption character. Corruption Eradication Commission published Anti-Corruption Education Module. The module easy to understand by the students because this is presented using simple language.

For the students of Primary Schools, the material of anti-corruption education module more emphasizes on nine values building anti-corruption attitude (honest, hard working, discipline, brave, responsible, independent, simple, fair and care). While for the students of Junior High School, it is added with definition of corruption itself and also the forms of corruption, including 30 definitions and categorized into 7 , for example bribery, extortion and embezzlement in office. For the students of Senior High School, this module is expanded with the material of state money, nation money and fighting against the corruption by young generation.

Table 1. The content of anti-corruption education material in civic education curriculum of school levels based on curriculum 2006

\begin{tabular}{lll}
\hline School & Grade & Competence standard \\
\hline Junior high school & Grade VIII, Semester 1 & $\begin{array}{l}\text { 3. Performing obedience toward } \\
\text { national regulation }\end{array}$
\end{tabular}
national regulation

Senior high school Grade X, Semester 1

2. Performing positive attitude toward national jurisdiction and law system

Grade XI, Semester 13 3. Performing open-minded and justice attitude in national and state life Specific basic competences

3.1. Identifying the sequence of national regulation

3.2. Describing the process of creating national regulation

3.3. Obeying national regulation

3.4. Identifying corruption cases and the effort to eradicate corruption in Indonesia 3.5. Describing definition of anti-corruption and the instruments (law and institution) of anti-corruption in Indonesia 2.1. Describing definition of law system and national jurisdiction

2.2. Analyzing the role of jurisdictional institutions

2.3. Performing attitude based on prevailed law rule

2.4. Analyzing the effort of corruption eradication in Indonesia

2.5. Performing participation and effort of corruption eradication in Indonesia

3.1. Describing definition and importance of open-mindedness and justice in national and state life

3.2. Analyzing the impact of untransparent governance performance

3.3. Performing open-minded and justice attitude in national and state life 
Table 2. Description of anti-corruption values and patterns of habituation in school

\begin{tabular}{ll}
\hline Values Description & Habituation in School \\
\hline $\begin{array}{l}\text { Honesty: } \\
\text { Behavior that is based on an attempt to }\end{array}$ & $\begin{array}{l}\text { Providing facilities for announcements of finding and missing items } \\
\text { make students as persons who always }\end{array}$ \\
believe in words, actions and work. & Prohibition of cheating \\
Responsibilities: & Establishing cafeteria with honesty concept \\
Attitudes and behaviors a person to & Implementation of regular post duty \\
perform duties on self, society, & active participation in school activities \\
environment (natural, social and & Asking trouble shooting suggestions \\
cultural), country and God Almighty & Submitting assignments on time \\
& Working duties in accordance with its role within the group \\
Simplicity: & Maintaining cleanliness, tidiness and beauty of the schools \\
Attitudes and behavior that are understated & Frugality in the use of school facilities (electricity, water, etc.) \\
(not excessive) & not arrogant \\
Freedom: & not bring fancy equipments (mobile phones, jewelry, gadgets, etc.) \\
Attitudes and behaviors which show & Atmosphere of democratic school \\
independency according to the rules & Teachers provide opportunities for learners to express opinions in \\
& free and responsible \\
& Learners are courageous to express their idea \\
& Providing a suggestion box \\
\hline
\end{tabular}

\section{Honesty Shop}

Paying close attention to such matter, Corruption Eradication Commission promotes the establishment of honesty shop in each school. Honesty shop is a shop selling snack and drink. It does not have seller. It is not guarded. Snack and drink are displayed in the shop. Through honesty shop, the students learn to be honest. The students learn to be obedient and faithful when there is no one watches over them. The core is anti-corruption education touches directly on affective and psychomotor domains. In Senior High School level, the example of honesty shop implementation is the opening of "Honesty Canteen" in SMA 8 Bandung, although it has not been maximal as the implementation of SMA 8 Bandung Motto: "Smart and have glorious moral". Honesty canteen is an effort to educate the students' moral to behave honestly. In this canteen, the students' awareness is very demanded to buy with payment and take the charge if it remains without being watched over by the teachers or shopkeeper. One of mottos emphasized in this canteen is God sees Angel records. Honesty shop is one of activities in anti-corruption education.

\section{Creating Anti-Corruption Climate at School}

School is one of environments influencing the success of anti-corruption values customization on the students' self. Positive modeling of anti-corruption by school management includes good modeling of school principal, administration staff and teachers as effective means to develop expected anti-corruption value, attitude and behavior. Anti-corruption behavior and attitude modeling that should be developed in school management are honest, hard working, discipline, brave, responsible, independent, simple, fair, care, open-minded and transparent values. Example Description of the anti- corruption values and Patterns of habituation in School can be seen in Table 2 .

\section{Discussion}

First, Civic Education is a subject caretaking the mission of anti-corruption education. It can be seen from the Normative Pinciple of National Education Minister No 22 Year 2006 about the content standard of curriculum: Emphasizing that the aim of civic education is to improve competences: (1) thinking critically, rationally and creatively in responding the citizenship issues; (2) participating actively and responsibly and acting firmly in societal, national and state activities and also anti-corruption; (3) developing positively and democratically to build self based on characters of Indonesia people in order to live together with other nations; (4) interacting with other nations in the world context directly or indirectly by using information technology and communication. It emphasizes that Civic Education should be able to implant anti-corruption attitude and behavior on students in all school levels.

Second, Contextual teaching and learning as AntiCorruption Learning Approach. This approach is effective because it assumes that learning process will occur completely if the students can find the meaningful correlation between abstract thinking and practical application in real context. In such learning experience, fact, concept, principle and procedure as subject material are internalized through discovering, enforcing, intercorrelation and integrating processes (Fogarty, 1991; Mathews and Cleary, 1993). Contextual learning is a coordination between subject material (content) and intellectual skill that should be had by students in condition and situation that are appropriate with students' cognitive psychology and learners' environment (Blanchard, 2001). Further, Johnson (2002) 
states that Contextual Teaching and Learning (CTL) helps students to see meaning in academic material that they learn by correlating the academic subjects and context in their daily lives, which is the context of their personal, social and cultural condition. Contextual learning in Civic Education influenced positively and significantly and contributed $26 \%$ to the civic competences of Junior High School student (Komalasari, 2009).

The characteristics of contextual learning according to Blanchard (2001) include: (1) relies on spatial memory, (2) typically integrated multiple subjects, (3) value of information is based on individual; (4) relates information with prior knowledge and (5) authentic assessment throught practical application or solving of realistic problem. Johnson (2002) identifies more completely eight components: (a) making meaningful connections; (b) doing significant work; (c) selfregulated learning (d) collaborating; (e) critical and creative thinking (f) nurturing the individual (g) reaching high standards and (h) using authentic assessment. Meanwhile, Sounders (1999) focuses on REACT (Relating: Learning in life experience context; Experiencing: Learning in searching and discovering context; Applying: Learning when knowledge was introduces in its usage context; Cooperating: Learning through interpersonal communication and share each other; Transferring; Learning to use knowledge in a new context or situation). Contextual learning is based on constructivism philosophy assuming that knowledge is the result of human construction. Human construct their knowledge through their interaction with object, phenomenon, experience and environment. Knowledge is assumed to be true if it can be useful in facing and solving an appropriate problem or phenomenon (Glasserfeld, 1996). Contextual learning according to Berns and Erickson (2001) and Komalasari (2012) can be implemented by five approaches: Problem-based learning, Project-based learning, Work-based learning, Service learning and Cooperative learning.

Third, value Education as The Essence of AntiCorruption Education. Anti-corruption education for students is directed to value education. Anti-corruption education supporting good values, according to Suseno (1987) is "education that makes people feel ashamed if they are tempted to do corruption and they feel angry if they see it". There are three fundamental moral attitudes that will make people invulnerable toward corruption temptation: Honesty, sense of justice and responsibility. Honest means being brave to state personal belief, showing him or herself. Honesty is a principal capital in collective living. Dishonesty will absolutely destroy collective living. The students should learn that behaving dishonestly is very bad thing. Just or fair means fulfilling others' rights and obeying all obligation of ourselves. Suseno (1987) states that behave well but violates justice is never good. Justice is a ticket to the goodness.
Responsible means being firm until the duty has been completed; diligent in completing obligation, for example, the students are given responsibility to manage the fund of sport activity at their school. The responsibility of students can be seen when the fund is spent as optimal as it can to succeed the sport activity. The improvement of responsibility is the most important part in educating children to be adult, to be quality people as human.

Value education is not stuck on values introduction. It should continue to the value understanding, values full comprehension and values implementation. Only by this round cycle, it is hoped that value education can bring the nation to the competence to reform self. For this reason, it needs transforming leadership; a type of leadership that can ask all nations to reform themselves. Theoritically, Lickona (1992) introduces the terms of values education, moral education for virtues" as educational process aiming to develop value and attitude. In indonesia, value education discourse is implicitly contained in civic education, which substantively and pedagogically has misión to develop the students into people who have national sense and love their country (National Regulation No. 20 Year 2003). In contextual civic education, which has value education as its core, can be developed various approaches as formulated by Superka et al. (1976), such as inculcation approach, cognitive moral development approach, values analysis approach, values clarification approach and action learning approach.

Fourth, Anti-corruption material can be enclosed as sub topic in civic education lesson. But, other question emerges: Is anti-corruption education only giving insight of cognitive domain? Anti-corruption education is not stuck on values inculcation and comprehension; it is not only memorizing; and it is not stuck on values inculcation. It is more than that, anti-corruption education touches on affective and psychomotor domains, building anti-corruption attitude and behavior on students toward anti-corruption values comprehension and implementation. It is related to the basic concept of value education by Hermann (1972) that theoritically states that "... values is neither taught nor cought, it is learned". It means that the substance of values is not only caught and taught, but they are processed, which means that they are caught, internalized and standardized as inherent part of personal quality through learning process. Learning process does not occur in free-culture space, but it occurs in culturerequiring community because we live in cultural community. Therefore, the process of education is basically enculturation process to create civilized people, including cultural people (Komalasari et al., 2014). Thus, value education is developed through standardization, customization, enculturation, direct parctice integrated in complex cultural system, including Civic Education class, school, family, peer-group, citizenship organization and mass media. 
Anti corruption Education in school's habituation is a process of acculturation, institutionalization and strengthening the anti-corruption values in accordance with the school climate (Saripudin, 2010). This reinforces Budimansyah (2010) that habituation is the process of creating a variety of situations and conditions (persistent-life situations). The situations and conditions contain a variety of reinforcement, which allows learners at their education unit, home and communities, to behave appropriate values and to make the value internalized and personalized as a character or a nature. With the habituation process, the students tend to perform actions or deeds that are relatively fixed and automatic so that the attitudes and actions tend to be stable. The attitudes or the behaviors that become habits have several characteristics. They are, among others, (a) the behavior is relatively settled; (b) the habituation generally does not require a quite high function of thinking, for example: Greeting can be thought or imitated; (c) The habit is not a result of maturity process, but as a result of experience or learning; (d) the behavior is performed repeatedly in response to the same stimulus (Budimansyah, 2010).

The implementation of the anti corruption education integration in habituation is based on behavioristic theory of Thorndike, Watson, Clark Hull, Guthrie and Skinner (Schunk, 2012). The theory states that the learning process is more emphasis on stimulus and responses that are emerged from the students. In this model, human qualities are observed from the aspects of performance/behavior that can be seen empirically (real). The patterns of stimulus and responses cover several points. The stimulus covers habituation processes and continuous repetition of behaviors in daily life at school. Response covers reinforcement by using a system of reward and punishment through the addition of point for achievement and reducing of points for offense. The integration of anti corruption education in habituation through this system will provide reinforcement to keep doing the expected behavior patterns and to reduce prohibited behavioral patterns.

\section{Conclusion}

The eradication of corruption is responsibility of all Indonesia people. Formal education has important role in implanting anti-corruption values since primary school to high school. Education to eradicate corruption should be in form of intersection between character education and civic education as nation and character building. Anti-corruption education integrated in content of curriculum of civic education and should be based on value learning and contextual teaching and learning approach. By such approach, anti-corruption values (honest, hard working, discipline, brave, responsible, independent, simple, fair and care) are known, understood, implanted and customized in the students' daily life. One example of anti-corruption values customization is the practice of honest canteen. Certainly, all efforts of anticorruption education at school should be supported by anti-corruption climate at school so that it gives good and positive model for the students.

\section{Acknowledgement}

This research is a grant from the Directorate General of Higher Education, Ministry of Education and Culture of Indonesia. The author would like to express sincere appreciation for all supports provided.

\section{Funding Information}

This article was funded by the Directorate General of Higher Education, Ministry of Education and Culture of Indonesia.

\section{Author's Contributions}

Kokom Komalasari: Designed the research plan and organized the study, data collection of the study sample, analysis and writing of the manuscript.

Didin Saripudin: Participated in all results analysis, contributed to the drafting of the article and reviewing it critically for significant intellectual content.

\section{Ethics}

This article is original and contains unpublished material. The corresponding author confirms that all of the other authors have read and approved the manuscript and no ethical issues involved.

\section{References}

Berns, R.G. and P.M. Erickson, 2001. Contextual teaching and learning: Preparing students for the new economy. The highlight zone: Research @ Work No. 5. ERIC.

Blanchard, A., 2001. Contextual Teaching and Learning. Educational services, Horizons Electronic Lesson Plans Resources.

Budimansyah, D., 2010. Penguatan Pendidikan Kewarganegaraan Untuk Membangun Karakter Bangsa. 1st Edn., Widya Aksara Press, Bandung, ISBN-10: 6029559095, pp: 244.

Fogarty, R., 1991. How to Integrate the Curricula Skylight Pub., Arlington Heights, Ill, ISBN-10: 0932935311, pp: 110.

Fraenkel, J. and N. Wallen, 2008. How to Design and Evaluate Research in Education. 8th Edn., McGraw-Hill Education, New York, ISBN-10: 0078097851, pp: 704. 
Gandamana, A., 2014. The implementation of anticorruption education through habituation and learning civics to build student's character (descriptive study in SMP 1 Cianjur, West Java).

Glasserfeld, E., 1996. Introduction: Aspects of Constructivism. In: Constructivism: Theory, Perspectives and Practice. Fosnot, C.T. (Ed.), Teachers College Press, ISBN-10: 0807772593, pp: 7-7.

Hermann, 1972, Value Theory (Axiology). J. Value Inquiry, 6: 163-184.

ICW, 2008. Corruption and Culture. Indonesia Corruption Watch, Jakarta.

Isra, S., 2009. Kekuasaan Dan Perilaku Korupsi: Catatan Hokum. 1st Edn., Penerbit Buku Kompas, Jakarta, ISBN-10: 9797093980, pp: 209.

Johnson, E.B., 2002. Contextual Teaching and Learning: What It Is and Why It's Here to Stay. 1st Edn. Corwin Press, Thousand Oaks, ISBN-10: 0761978658, pp: 196.

Keen, E., 2003. Fighting corruption through education. Open Society Institute, Hungary.

Koentjaraningrat, 2000. Kebudayaan, Mentalitas Dan Pembangunan. 1st Edn., Gramedia Pustaka Utama, Jakarta, ISBN-10: 9796860058, pp: 151.

Komalasari, K., 2009. The effect of contextual learning in civic education on students' civic competence. J. Social Sci., 5: 261-270. DOI: $10.3844 /$ jssp.2009.261.270

Komalasari, K., 2012. The living values-based contextual learning to develop the students' character. J. Social Sci., 8: 246-251. DOI: $10.3844 /$ jssp.2012.246.251

Komalasari, K., D. Saripudin and I.S. Masyitoh, 2014. Living values education model in learning and extracurricular activities to construct the students' character. J. Edu. Pract., 5: 166-174.
Lickona, T., 1992. Educating for Character: How Our Schools can Teach Respect and Responsibility. 1st Edn. Bantam, New York, ISBN-10: 0553370529, pp: 478.

Lincoln, Y.S. and E.G. Guba, 1985. Naturalistic Inquiry. 1st Edn., SAGE Publications, Beverly Hills, ISBN-10: 0803924313, pp: 416.

Mathews, B. and P. Cleary, 1993. The Integrated Curriculum in Use: Practical Ideas for Planning and Assessment. 1st Edn., Ashton Scholastic, Sydney, ISBN-10: 1863880585, pp: 102.

National Regulation No. 20 Year 2003 about National Education System. Indonesian Goverrment, Jakarta.

Normative Principle of National Education Ministry No 22 Year 2006 about the content standard of Curriculum. National Education Ministry of Indonesia, Jakarta

Saripudin, D., 2010. Interpretasi Sosiologis Dalam Pendidikan. 1st Edn., Karya Putra Darwati, Bandung, pp: 202.

Schunk, D.H., 2012. Learning theories: An educational perspective. 6th Edn., Pearson Education, New York, ISBN-10: 0137071957, pp: 576.

Sounders, 1999. Contextually based learning: Fad or proven practice. Washington DC USA: American Youth Policy Forum.

Superka, D.P., C. Ahrens, J.E. Hedstrom, L.J. Ford and P.L. Johnson, 1976. Values Education Sourcebook: Conceptual Approaches, Materials Analyses and an Annotated Bibliography. 1st Edn., Social Science Education Consortium, Boulder, pp: 259.

Suseno, F.M., 1987. Etika Dasar: Masalah-Masalah Pokok Filsafat Moral. 1st Edn., Kanisius, Yogyakarta, pp: 156. 